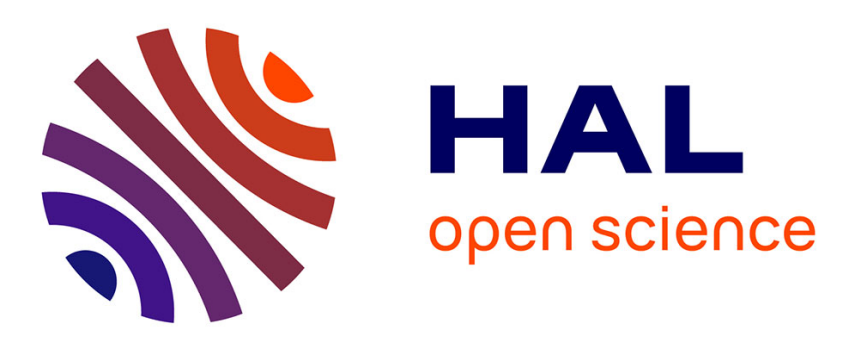

\title{
The U-Shaped Productivity Dynamics of French Exporters
}

Flora Bellone, Patrick Musso, Lionel Nesta, Michel Quéré

\section{To cite this version:}

Flora Bellone, Patrick Musso, Lionel Nesta, Michel Quéré. The U-Shaped Productivity Dynamics of French Exporters. 2007. hal-00973046

\section{HAL Id: hal-00973046 \\ https: / hal-sciencespo.archives-ouvertes.fr/hal-00973046}

Preprint submitted on 3 Apr 2014

HAL is a multi-disciplinary open access archive for the deposit and dissemination of scientific research documents, whether they are published or not. The documents may come from teaching and research institutions in France or abroad, or from public or private research centers.
L'archive ouverte pluridisciplinaire HAL, est destinée au dépôt et à la diffusion de documents scientifiques de niveau recherche, publiés ou non, émanant des établissements d'enseignement et de recherche français ou étrangers, des laboratoires publics ou privés. 


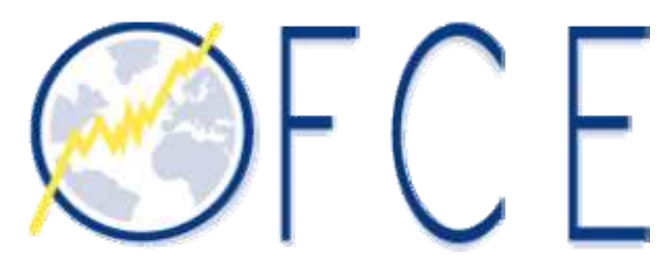

\section{Document de travail}

\section{The U-Shaped Productivity Dynamics of French Exporters}

$\mathrm{N}^{\circ}$ 2007-01

Janvier 2007

Flora Bellone (Université de Nice)

Patrick Musso (CNRS)

Lionel Nesta (OFCE)

Michel Quéré (CEREQ) 


\title{
The U-shaped Productivity Dynamics of French Exporters
}

\author{
Flora Bellone * \\ Patrick Musso ${ }^{\dagger}$ \\ Lionel Nesta $\ddagger$ \\ Michel Quéré $\S$
}

January 4, 2007

\begin{abstract}
Sunk costs due to entry into foreign markets are used as the main justification of the relationship between firm productivity and exports. We use a large-scale dataset on French manufacturing firms to evaluate how sunk costs affect the productivity of new exporters. We find that the typical productivity dynamics of a new exporter is U-shaped. Prior to entry into export markets, firm productivity temporarily decreases. It recovers contemporaneously with entry, as the benefits from sales to foreign markets are harvested. This pattern is more pronounced for intensively exporting firms and for firms operating in capital intensive or high technology sectors.
\end{abstract}

\section{Introduction}

Analysis of firm heterogeneity has benefited from the field of international trade by exploiting the models provided by Melitz (2003) and Bernard, Eaton, Jensen, and Kortum (henceforth BEJK, 2003) in which firms' export behaviour is largely driven by differences in productivity. Both these models emphasise the notion of sunk costs for explaining the relationship between firm productive efficiency and participation in export activity. They contend that only the most productive firms find it profitable to serve distant markets and that less productive ones concentrate on domestic market. On the empirical side, there is a series of papers that document the superior productive

\footnotetext{
*Université de Nice Sophia-Antipolis, Avenue Doyen Trotabas, 06050 NICE Cedex 1. Email: bellone@gredeg.cnrs.fr

${ }^{\dagger}$ CNRS-GREDEG, 250 rue Albert Einstein, Valbonne - Sophia Antipolis, 06560 France. Email: musso@gredeg.cnrs.fr

$¥$ Observatoire Français des Conjonctures Economiques , Département de Recherche sur l’Innovation et la Concurrence, 250, rue Albert Einstein , 06560 Valbonne - France. Email: lionel.nesta@ofce.sciences-po.fr

$\S$ CEREQ, Marseille, Email: quere@cereq.fr
} 
efficiency of exporting firms compared to non exporting ones Bernard and Jensen (1995, 1999), Clerides et al. (1998), Bernard and Wagner (1997) and Aw et al. (2000). The hypothesis that firms self-select into export markets is further examined by comparing the productivity of future exporters and non- exporters at a particular point in time, prior to entry into export markets. The observed productive superiority of future exporters is usually interpreted as indirect evidence of the presence of sunk costs.

This paper contributes to this literature in providing a more accurate assessment of how sunk costs of entry into export markets impact the productivity dynamics of new exporters. Our research hypothesis is that sunk costs imply prior investments, which are compensated for by future rather than contemporaneous profits, namely those linked to the expansion of sales on foreign markets. This temporal disconnection between costs and receipts can be more or less significant depending on the nature of sunk costs (e.g. setting up new distribution channels, adapting the specifications of outputs and/or inputs, building new production facilities, investing in new technologies to fit specific requirements on international markets, etc...). In all cases, sunk entry costs associated to an export strategy imply time-to-build constraints which should decrease the productivity of future exporters for at least some period before actual entry into export. This implies that the productivity dynamics of future exporters should be U-shaped. We test for this pattern using a large scale micro-level dataset of French manufacturing firms over the period 1990-2002. It is notable that data on France have not yet been included in the available evidence on the relationship between export and firm productivity. A few recent papers on the export behaviour of French firms have examined the relationship between trade, agglomeration and firm structure ${ }^{1}$ (see in particular Eaton et al. (2004) and Koenig (2005)). However, none of these studies specifically investigates the relationship between export and productivity dynamics.

Our methodology follows that suggested by Bernard and Jensen, with three notable amendments. First, we trace the relative performance of firms over a longer time span in order to depict the dynamics of the productivity gap between new exporters and their non-exporting counterparts, namely five years before and after entry into the export market. This eleven-year window enables us to identify a U-shaped productivity pattern while holding constant a host of factors that might influence it. Second, we unravel the productivity dynamics of exporters by setting the benchmark value for each firm at a unique point in time. This allows us to fully account for the presence of a U-Shaped pattern as we compare the performance of new exporters relatively to themselves and not only relatively to their non-exporting counterparts. Finally, we investigate how pre-entry costs and also post-entry gains behave according to the different types 
of industry, grouped by mean capital intensity and technological intensity. This enables us relate the sensitivity of the U-shaped productivity pattern with the type of productive activity the new exporter is involved in.

The results from the French data strongly support the idea that the productivity dynamic of new exporters is a U-shaped curve. The typical Total Factor Productivity (TFP) path of a new exporting firm in France is one along which its advantage (over non exporting firms) temporarily vanishes during the run-up to entry, on average three years, to appear again as a contemporaneous effect of entry into exporting. Labour productivity show a similar, albeit less pronounced, pattern, in which future exporters maintain their significant advantage over nonexporters even during the run-up phase. We interpret these results as suggesting that sunk costs linked to entry into export markets are primarily composed of capital and intermediate inputs as changes in those two components are what bear the most heavily on firm performance during the pre-entry period. Moreover, this U-shaped productivity dynamics is robust to different subsample composition. It is more pronounced for firms in the capital intensive and high technology sectors and for firms that commit significantly to exporting. This latter result is consistent with the idea that an intensively exporting firm is more likely to serve several foreign destinations. Consequently, it may face higher sunk costs due to trade-link investments that are market specific rather than product-specific (Andersson and Johansson (2006)).

The paper is organised as follows. Following a short review of the literature in Section 2, Section 3 describes the dataset used in this paper and provides preliminary evidence on exporting by French manufacturing firms. In Section 4, we provide information on the sources of the export premium in French manufacturing industries. In Section 5, we document the U-shaped productivity dynamics of firms preparing for foreign markets. Concluding remarks are presented in Section 6 .

\section{Literature Background}

Since the pioneering work of Bernard and Jensen (1995, 1999), a growing body of empirical evidence has shown that firms that participate in export markets are more productive, larger, survive longer and pay higher wages, than firms that focus exclusively on domestic markets. Two main mechanisms have been proposed to explain the positive relationship between exports and productivity. First, only efficient firms find it profitable to export because only such firms can cope with the sunk costs associated with the penetration of foreign markets. This self- 
selection hypothesis has been incorporated into models of international trade involving firm heterogeneity and exporting sunk costs (Melitz, 2003; Bernard et al., 2003; Helpman et al., 2004; Yeaple, 2005; Melitz and Ottaviano, 2005; Jean, 2002; Medin, 2003). Second, firms participating in export markets have access to different knowledge and technical expertise from domestic markets, including new product designs and new production methods. This expertise results in improvements in the productive efficiency of exporting firms. This idea of learning-by-exporting, advanced by Westphal (1990), Pack and Page (1994), Evenson and Westphal (1995) and Nelson and Pack (1999) among others, was integrated by Clerides et al. (1998) into a theoretical model of the decision to export.

An increasing number of studies has attempted to evaluate the relative importance of these self-selection and learning mechanisms in explaining the positive correlation between productivity and exports at firm-level. All these studies use large scale longitudinal micro data-sets and apply advanced micro-econometrics techniques to investigate these issues ${ }^{2}$. They use a variety of methodologies ranging from panel data regressions to binary choice models to explain the decision to export. More recently, matching methods and difference-in-difference techniques have been applied in an attempt to explore more accurately whether an exporting firm can obtain additional improvements from exposure to foreign markets (see Girma et al. (2004) for a presentation of these methodologies).

To collect country case-studies is useful because the observed importance of self-selection mechanisms and learning-by-exporting effects is likely to vary across countries ${ }^{3}$. Recent surveys (Lopez, 2005; Greenaway and Kneller, 2005; Wagner, 2005) have nonetheless emphasised some significant common findings. First, most country-case studies document a significant productivity gap between future exporters and their non-exporting counterparts. This ex ante export premium has been interpreted as reflecting the presence of sunk costs associated with entry into foreign markets and then as supporting the self-selection hypothesis. Although persistent, the gap between future exporters and non-exporting firms varies across countries. The strongest selection effects were found for the US, Colombia and Canada, with a TFP advantage of about $7 \%$ for future exporting plants over non exporting ones ${ }^{4}$. At the other extreme, two studies, on Korea and Sweden respectively, failed to document any significant dufferences between exporters and non exporters. In Korea, Aw et al. (2000) refer to the specific role of government investment subsidies in weakening market selection forces. For Sweden, Greenaway et al. (2005) point to the remarkably high participation rate of Swedish firms in export markets (around 91\%) to explain the lack of self-selection mechanisms. With a high degree of international exposure, non-exporters 
already compete with firms engaged in export activity and through import penetration.

On learning effects, the literature is far less unanimous. Overall, learning-by-exporting appears to be a more difficult concept than self-selection effects. In the case of industrialised countries, there is mixed evidence. For Germany (Bernard and Wagner, 1997), the US (Bernard and Jensen, 1999), Spain (Delgado et al., 2002) and Japan (Kimura and Kiyota, 2006), there is no evidence supporting learning mechanisms ${ }^{5}$; stronger evidence was found for Italy (Castellani, 2002), the UK (Girma et al., 2004) and Canada (Baldwin and Gu, 2003). It could be argued that one would expect plants or firms to learn more from participation in international trade in countries where the distance from the productivity frontier is greater. Studies on industrialising countries, however, do not yield more clear-cut evidence. Studies on Colombia, Mexico, and Morocco (Clerides et al., 1998), Taiwan and Korea (Aw et al., 2000) and Chili (Alvarez and Lopez, 2005) failed to find evidence of learning-by exporting. Only for China (Kraay, 1999) and for a panel of Sub-Saharan countries (Van Biesebroeck, 2005), have significant post-entry productivity gains been documented.

The present study adds to this literature in expanding the set of available evidence on selfselection and learning-by-exporting, to another important trade partner, namely France. We also go beyond previous studies by looking more accurately at the dynamics of future exporters' productivity. Our empirical investigation is driven by the idea that the sunk costs of entry into foreign markets involve prior investments which are compensated for by future not contemporaneous profits. This temporal disconnection is likely to be more or less pronounced depending on the contents of sunk entry costs into export markets. For instance, if the entry into export markets requires to set up new international distribution channels, instead of relying on existing ones, this will take more time. Also, if the entry into export markets requires to change the intermediate input and/or output mix, to build specific production capacities and/or to invest in specific technologies, the export strategy of the firm can encompass even stronger time-to-build constraints. All in all, sunk entry costs should weigh negatively, although temporarily, on the relative performance of exporting firms. Such a drop in relative TFP for otherwise successful firms was recently documented by Altomonte and Barratieri (2006) using Italian product and firm-level data. They show that firms in industries facing competition from low-wage countries have survived and grown because they changed their product-mix and accepted larger fixed costs, which produced a fall in average TFP for the industry. Bernard et al. (2005) theoretically modeled the possibility that, in switching products, the resulting average industry productivity might be lower, since the new products are characterised by higher fixed costs. In the context of 
new exporters, it is however likely that the decrease in the productivity of new exporters will be temporary. First, some of the sunk costs of entry to export markets are incurred only once (for instance, setting up the distribution channels). Second, the entry into export markets is likely to cause further increases in productivity. We consequently argue that the productivity dynamics of new exporters is U-shaped.

To investigate this, we exploited a large-scale firm-level dataset of manufacturing companies, covering the period 1990-2002. This dataset is particularly suited to our study for three main reasons. First, the series is long enough to track the relative performance of new exporters over a sufficient time span to depict the presence of a U-shaped pattern. Indeed, detecting the presence of sunk costs is not a case of measuring relative productive efficiency at one point in time, but involves the time lag between specific export investments and returns from exports. Consequently, focusing exclusively on a unique point estimate, typically one, two or three three years before entry into export markets is not appropriate. The productivity dynamics can only be captured by pushing the point estimates both further back in time and also nearer to the time of entry. In this way, we can examine not how wide the gap between exporters and non exporters is at a specific point in time, but in what direction and how quickly the gap changes before entry.

A second advantage of French data is that they are collected at firm rather than plant level. This allows us to depict more accurately the impact of the sunk entry costs. Indeed, suppose that a non-exporting firm comprising several establishments decides to export a share of its production to foreign markets. This firm will have to cope with a series of sunk costs which will appear on the balance sheets at the consolidated level via an above-normal increase in investments. Those investments may consist of building additional productive capacities (i.e. new plant), consolidating the distribution networks (i.e. setting up an office overseas), which will affect the parent company's balance sheet, but not that of the individual plants within the firm. Therefore, the use of firm-level data will likely identify sunk costs better than plant level data.

Finally, the French dataset provides information at the four-digit industry level classification level. This allows us to discriminate across fine-grained industry classifications according to their capital and technological intensity. If sunk costs associated with entry into export markets differ across industries, then the U-shaped could be more pronounced for firms operating in capital intensive and/or high technology industries. Indeed, in both types of industries, firms targeting export markets are likely to face stronger time-to build constraints prior to export due to specific requirements on foreign markets. In this paper, we also investigate whether the 
U-shaped pattern is sensitive to the export intensity of the firm. Here the rational is different: if the export intensity of a firm is correlated with the number of foreign markets it serves, then entry cost into exports will be proportional to the export intensity at firm level.

\section{The export premium in France}

In order to characterise the relative performance of exporting firms within French manufacturing, we use the firm dataset collected by the French Ministry of Industry (SESSI). The French Manufacturing Census (known as EAE) is a unique survey designed to gather information on the financial statements and balance sheets of all manufacturing firms with at least 20 employees. This dataset covers about 23000 firms by year over the period from 1990 to 2002 . Those firms represent only $25 \%$ of all manufacturing firms in France but account for $75 \%$ of employment and $80 \%$ of value added in French manufacturing. Having information on nominal gross output, a series of inputs (such as number of employees, intermediates inputs, investments, etc.), and exports, we can investigatethe relationship between exporting and productive efficiency in France.

[Table 1 about here.]

Table 1 summarizes basic information about the export behaviour of French firms. It displays the number of all manufacturing firms, and the percentage of exporting firms, i.e. the participation rate, by sector at the 2-digit level. It also displays export-to-sales ratios, i.e. export intensities, at both industry and firm levels ${ }^{6}$. The last column presents the size of exporting relative to non exporting firms. We can see that in all manufacturing sectors, there is a substantial number of firms (73\%) engaged in foreign trade, suggesting that exporting and non exporting firms coexist in all types of productive activities ${ }^{7}$. Second, the arithmetic mean of firm export intensity is half that for sector export intensity for all manufacturing, implying that large firms export a larger share of their production ${ }^{8}$.

[Table 2 about here.]

Overall, these figures show that French manufacturing firms participate substantially in international trade. But how do they compare with other OECD countries? Table 2 presents the participation rates and the (average) firm export intensities of other countries. Direct comparisons across countries are not really feasible because of the differences in data sources. In 
particular, plant-level data introduce a downward bias in participation rates compared to firmlevel data, simply because exporting firms may have non exporting plants. Nevertheless, , table 2 reveals some interesting patterns: France scores higher than the US in terms of participation rate and firm export intensity; French manufacturing firms are more heavily involved in exporting than their British and Spanish counterparts, but less so than Swedish firms; French firms' export behaviour is closest to that of Italian firms, in terms of both participation and intensity; the mean value of export intensity at firm level is lower for France than for most other countries, except the US. These results suggest that, in general, a smaller proportion of French firms' sales go to export compared to other major players such as Great Britain, Spain and Sweden.

[Table 3 about here.]

Table 3 reports mean export intensity and participation rate by size of firms. There are two things to note from this table. First, the export-to-sales ratio of small firms is less than half that of larger firms (16.3\% versus $34.4 \%)$. Based on the international evidence available here, we can see that the export intensity of small firms in French manufacturing is similar to that of small firms in Italy (Castellani, 2002) and less than that of Spanish firms, which is around $20 \%{ }^{9}$.On the other hand, large French firms do not show weaker export intensity than either Italian or Spanish firms. Second, the gap in the participation rates of small and large firms increases with the export-to-sales threshold. Whereas almost all large firms participate in international trade, only $60 \%$ of small firms are active in foreign markets. This gap widens as the minimum threshold of export intensity increases. For example, we find that $75 \%$ of very large firms export at least $10 \%$ of their sales. This ratio is three times larger than that for small firms. This implies that the SMEs are mainly responsible for the lower average export intensity in France; for large firms levels of both participation in international trade and export intensity are comparable to the findings from other studies (Bernard and Jensen, 1999; Delgado et al., 2002; Castellani, 2002).

Investigating why French SME's are less active in international trade than some of their European counterparts is beyond the scope of this paper. However, we can see that French exporters are much larger than their non-exporting counterparts, which is in line with the export premia documented below. Export premia are defined as systematic differences in some characteristics of exporting firms compared to non-exporting ones, that are over and above mere industry effects, year specific effects or cohort effects. Specifically, we look at a series of variables $X_{i t}$, where subscripts $i$ and $t$ stand for firm $i$ at time $t, X$ is alternatively Output (Y), Labour (L), labour productivity $(\mathrm{Y} / \mathrm{L})$, capital intensity and wage per employees (these variables are fully described 
in Appendix A). We subtract from all $X_{i t}$ the industry fixed effect $s_{j}$, a year fixed effect $d_{t}$ and cohort fixed effect $v_{c}$ in order to obtain $X_{i t}^{\prime}=X_{i t}-s_{j}-d_{t}-v_{c}$, where all fixed effect are defined as differences of group means from overall sample mean. Table 4 presents the results for all firms and each size class, together with the mean number of (non-) exporting firms per year. All reported values for firm characteristics are expressed relative to non-exporting firms. ${ }^{10}$

[Table 4 about here.]

For the whole sample of firms, Table 4 reveals a strong export premium for the five characteristics: relative to non-exporting firms, exporters produce 2.5 times more, are twice as large, are $40 \%$ more labour-productive, are $24 \%$ more capital intensive, and pay their employees $10 \%$ more. Moreover, in line with Bernard and Wagner (1997) and Castellani (2002)), we find that export premia do not disappear in more narrowly defined size-classes of firms. Within each of our four size-classes, the average French exporter displays a labour productivity advantage of around $30 \%$.

\section{The Sources of The Export Premium}

The preceding section revealed the magnitude of the export premium in France. The next step is to investigate the relative importance of market selection forces versus learning-by-exporting in driving this export premium. We do this by examining the causal relationship between firm productive efficiency and firm export behaviour. We adopt the methodology proposed by Caves et al. (1982) and Good et al. (1997) to compute TFP indexes (see Appendix B for details). We then examine the relationship between firm-level relative TFP indexes and both export participation and export intensity variables.

\subsection{The TFP bonus of French Exporters}

TFP should be a more precise indicator of productive efficiency than mere labour productivity in that it accounts for both capital intensity and capital productivity. Table 5 presents the mean TFP values ${ }^{11}$ for the four types of firms found in our dataset: those that always export (Always Exporters - AEs) over the whole time period, those that did not export initially, but became exporters between 1990 and 2002 (New Exporters - NewEs), those that year to year entered or exited from international markets (Switchers), those that concentrated exclusively on the domestic market (Never Exporters- NEs). Table 5 presents the results for firms present during 
the whole time span of the investigation (balanced panel) and for successful entrants, that is, entrants that survived at least 5 years.

[Table 5 about here.]

The first column of Table 5 reports the TFP mean values for all firms in the sample (export-tosales ratio $\geq 0$ ) with the mean TFP value of NEs, as the benchmark, set to 100. As expected, we can see that firms that participate in international trade are on average more productive than the ones which never export. This TFP bonus increases with persistency of export behaviour: NEs are less productive than Switchers; Switchers are less productive than NewEs, who in turn are less productive than AE's. Lastly, the bonus increases with the firm's commitment to international trade, as demonstrated by the export-to-sales ratio. The productivity premium widens as the firm's share of sales dedicated to international markets expands ${ }^{12}$.

The sub-division of the sample into Continuing firms and Successful entrants shows where the best firms are "located". They belong to a sub-group of Entrants, which includes firms that were involved in exporting from the first year that they entered the market ${ }^{13}$. This sub-sample not only outperforms the sub-sample of Entrants which sequentially enter the market, and eventually begin to export (NewEs). It also outperforms the sub-sample of the most productive units in the class of continuing firms, namely the AEs. This result is in line with Hallward-Driemeier et al. (2002) recent findings for a panel of East-Asian Countries and Alvarez and Lopez (2005) findings for Chile. It may indicate that the selection of the firms which are going to export is not a random process determined by exogenous productivity shocks, as portrayed by Melitz (2003) canonical model. On the contrary, it could be that the firms that are established exporters are more productive than those that eventually become exporters, because they make conscious decisions about technologies when they target the export markets ${ }^{14}$. It is beyond the scope of this paper to try to discriminate between random and conscious self-selection, however. We turn now to the evaluation of how much of the productivity gap between NewEs and NEs is due to ex-ante differences in productivity performance and how much is due to post-entry differences.

\subsection{Firm Performance Before Entry into Export}

In a first step, we test the idea that firms that become exporters are more productive before they enter into foreign markets. If this holds, future exporters should outperform non exporting firms in terms of productive efficiency some years before entry into foreign markets. To validate this proposition, we follow Bernard and Wagner (1997) and Bernard and Jensen (1999) and select 
only those firms that do not export in $t-\tau, \cdots, t-2$ and $t-1$, but may export in $t$. Parameter $\tau$ takes alternatively values $\{3 ; 5\}$, controlling for different time lags in the productivity premium for future exporters. Thus, we select New Exporters (which do not export for at least $\tau$ years) and Never Exporters to regress the $(\log )$ value of TFP at time $t-\tau$ on the export status at time $t^{15}$. We have:

$$
\begin{aligned}
\ln T F P_{i, t-\tau} & =\alpha+\beta \times E_{i t}+\gamma \times S i z e_{i t-\tau}+\sum_{j t-\tau} \delta_{1 j t-\tau} \times\left(S_{j} \cdot D_{t-\tau}\right) \\
& +\sum_{c} \delta_{2 c} \times C_{c}+\varepsilon_{i, t-\tau}
\end{aligned}
$$

where $E_{i t}$ is a dummy variable set to unity if firm $i$ starts exporting at time $t$ (i.e. New Exporters), $S i z e_{i t}$ is the number of employees at time $t-\tau$ and $S_{j}, D_{t-\tau}$ and $C_{c}$ are vectors of dummy variables controlling respectively for sector, time and cohort specific effects ${ }^{16}$.

In addition to looking at differences in TFP levels, we also examine the run-up to exporting in terms of whether and how firms prepare for international markets. Thus, we consider firms' growth performance by regressing the TFP growth rates of New Exporters and Never Exporters on the same vector of explanatory and control variables, as follows:

$$
\begin{aligned}
\Delta \ln T F P_{i, \frac{t-\eta}{t-\tau}} & =\frac{1}{\tau-\eta} \times\left(\ln T F P_{i, t-\eta}-\ln T F P_{i, t-\tau}\right) \\
& =\alpha+\beta \times E_{i t}+\gamma \times S_{i z e_{i t-\tau}}+\sum_{j t-\tau} \delta_{1 j t-\tau} \times\left(S_{j} \cdot D_{t-\tau}\right) \\
& +\sum_{c} \delta_{2 c} \times C_{c}+\varepsilon_{i, \frac{t-\eta}{t-\tau}}
\end{aligned}
$$

where $E_{i t}, S_{i z e_{i t}}, S_{j}, D_{t-\tau}$ and $C_{c}$ are defined as before. Eq.2 tests whether the mean annual growth rate between $t-\tau$ and $t$ is significantly different for New Exporters as opposed to Never Exporters. Furthermore, in order to grasp more accurately the timing of the run-up phase, we introduce the TFP growth rates between different time intervals, such that parameters $\eta$ and $\tau$ take the successive values $\{3 ; 1 ; 0\}$ and $\{5 ; 3 ; 1\}$. This is useful to detect whether an observed change in TFP growth rate is contemporaneous with entry into the export market (Eq.2) and whether it is due to the preparation phaseprior to foreign market penetration.

The idea that new exporters self-select into export markets should translate into a significant and positive sign of $\beta$ in either Eq.(1) or 2. Such a finding based on French data would be 
consistent with the self-selection hypothesis. Non significance would imply no self-selection, rejecting the view that only efficient firms can cope with the sunk costs associated with foreign market penetration. Negative significance would be more difficult to interpret as it would entail adverse selection.

Table 6 reports estimates for $\beta$ for Eq. 1 and Eq.2. Note that as TFP is the joint product of real output as a function of capital stocks, labour and intermediate inputs. We also show the results using the $\log$ values of $Y$ (real output), $K$ (real output), $L$ (labour) and $M$ (materials) as dependent variables, with labour productivity as an additional dependent variable for robustness checks.

[Table 6 about here.]

Looking first at the results of Eq.1, we find that five years before entry into foreign markets future exporters display a productivity advantage of more than $3 \%$ over the firms which will never export. However, three years before entry $(\tau=3)$, future exporters face a significant and negative TFP disadvantage; they appear to be $2 \%$ less productive than NEs. This result is at odds with prior empirical contributions, for example, Bernard and Jensen Bernard and Jensen (1999), which show that three years before exporting, future US exporting plants are $6 \%$ more productive (in terms of TFP) than their never exporting counterparts.

In fact, the decrease in TFP level of NewEs is principally due to the growth in capital stocks relative to NEs, of $30 \%$ larger than NEs ( $27 \%$ three years before entry). In turn, in terms of labour productivity, NewEs retain a small but significant advantage over NEs for the whole time span. This finding then validates the idea that new exporters have to face specific sunk costs before actual exports take place, such as building specific capital stocks and securing distribution channels. These investments are intrinsically time-consuming and may help to explain the lag in the productivity-export relationship. In our view, this sharp decrease corresponds to the sunk costs associated with entry into export markets, that are incurred.

Looking at growth rates in the three last Columns of table 6 (Eq.2), we find that future exporters cope with a 1.6 percentage points lower TFP growth rate lower than never exporters, between $t-5$ and $t-3$. This is the result of inputs growing faster than outputs, relative to Never Exporters. Column 4 presents estimates for the run-up phase between $t-3$ and $t-1$, and shows sustained growth for both inputs and output, implying that neither labour nor TFP grow at significantly different rates compared to those of Never Exporters. In fact, the changes in TFP and labour productivity growth rates are contemporaneous with the first year of export 
activity. Between $t-1$ and $t$, all characteristics of future exporters undergo considerable changes: output grows 14 percentage points faster than for Never Exporters; intermediate inputs grow by almost 20 percentage points; labour and capital stocks expand by circa 5 percentage points. Thus, exporters enjoy significantly faster growth rates, 8 and 3 percentage points respectively for labour productivity and TFP. In other words, firms starting to export, experience salient productivity improvements contemporaneous with the first year of export. This implies that exporting firms may also experience higher TFP growth rates than Never Exporters after their entry into foreign markets. This issue is investigated below.

\subsection{Firm Performance After Entry into Export}

In examining firm performance after entry into export markets, we would expect NewEs to outperform NEs. Recall that we found there was a TFP bonus for exporting firms and that this bonus disappears for NewEs during the run-up to entry into export markets. One could expect then to observe at least a recovery of the productivity advantage of exporters in the years after their entry into foreign markets. To evaluate the precise magnitude of ex-post productivity gains, we looked at the TFP performance of exporters relative to non exporters $n$ years after entry into export markets at time $t$. With $n$ set arbitrarily to 5 years, we have:

$$
\begin{aligned}
\ln T F P_{i, t+5} & =\alpha+\beta_{1} \times E_{i t}+\beta_{2} \times E I_{i t}+\gamma \times S i z e_{i t}+\sum_{j t} \delta_{1 j t} \times\left(S_{j} \cdot D_{t}\right) \\
& +\sum_{c} \delta_{2 c} \times C_{c}+\varepsilon_{i, t+5}
\end{aligned}
$$

where again $E_{i t}$ is a dummy variable set to unity if firm $i$ starts exporting at time $t$ (i.e. New Exporters), and $S_{j}, D_{t}$ and $C_{c}$ are vectors of dummy variables controlling respectively for sector, time and cohort specific effects. As in Castellani (2002) and Girma et al. (2004), we augment the baseline specification using export intensity as an additional explanatory variable. The reason for this is to test whether in addition to the decision to export there is another driving force in the form of productive efficiency related to the share of production dedicated to export markets. 


$$
\begin{aligned}
\Delta \ln T F P_{i, \frac{t+\eta}{t+\tau}} & =\frac{1}{\eta-\tau} \times\left(\ln T F P_{i, t+\eta}-\ln T F P_{i, t+\tau}\right) \\
& =\alpha+\beta_{1} \times E_{i t}+\beta_{2} \times E I_{i t} \\
& +\gamma \times S i z e_{i t}+\sum_{j t} \delta_{1 j t} \times\left(S_{j} \cdot D_{t}\right) \\
& +\sum_{c} \delta_{2 c} \times C_{c}+\varepsilon_{i, \frac{t+\eta}{t+\tau}}
\end{aligned}
$$

where $E_{i t}, S_{j}, D_{t-3}$ and $C_{c}$ are defined as before, and parameters $\eta$ and $\tau$ takes the successive values $\{5 ; 3\}$ and $\{3 ; 0\}$. Eq.4 tests whether the mean annual growth rate between $t+\tau$ and $t+\eta$ is significantly different for New Exporters relative to Never Exporters. In this case, a significant and positive sign for $\beta_{1}$ implies that New Exporters enjoy higher TFP growth rates in percentage points, compared to Never Exporters. This is the basic specification proposed by Bernard and Wagner (1997) and Bernard and Jensen (1999). Moreover, we augment the model following Castellani (2002) and Girma et al. (2004) and include export intensity (EI) in order to test whether the source of TFP growth is due to mere participation in international trade or is proportional to export intensity. Previous results suggest that $\beta_{2}$ could be expected to be significantly positive.

[Table 7 about here.]

Table 7 displays the results for Eqs.(3) to (4). The first two columns present the results when the dependent variable TFP is introduced in levels. There is a significant and positive effect for the export-to-sales ratio $\left(\beta_{2}\right)$, whereas the export dummy $\left(\beta_{1}\right)$ is at the borderline of significance. At the $10 \%$ level, NewEs are $2 \%$ more productive than NEs five years after their initial exports. Interestingly, firms that devote a larger share of their sales to exports are more productive: a 10 percentage-point rise in their export-to-sales ratio equates with almost a $0.7 \%$ increase in TFP differential relative to NEs $(0.67 \%)$, and a $2 \%$ increase in labour productivity relative to Never Exporters $(1.84 \% \text {, at the } 10 \% \text { level })^{17}$. These results conceal sharper differences between both types of firms in all characteristics. Five years after first exports, NewEs produce almost $30 \%$ more than Never Exporters $(29.9 \%)$ and have a $14 \%$ bigger labour force $(13.8 \%$, in terms of hours worked), and $40 \%$ larger capital stocks (38.0\%).

The existence of post-entry TFP gains, larger the higher the export intensity, echoes previous results found by Castellani (2002) and Girma et al. (2004). It could reveal the presence of 
learning-by-exporting effects which, in the case of France, would concern only the small fraction of intensively exporting firms. However, we investigate the timing of these changes further by looking at the changes between $t$ and $t+3$ and between $t+3$ and $t+5$ (Eq.4). Table 7 reveals that none of the average yearly TFP growth rates, either between $t$ and $t+3$ or between $t+3$ and $t+5$ is significant. Those results do not comfort the learning-by exporting hypothesis ${ }^{18}$.

This is not to say that exporting is not a source of productive efficiency gains. In fact, we can see that over a period of three years, the growth rates for all firm characteristics are significantly higher for NewEs. Thus firms that become exporters experience spectacular changes in terms of the size of their operations after entry into exporting. Since NewEs enjoy higher rates of output growth than their non-exporting counterparts (by almost 3 percentage points), it could be that improvements in the productive efficiency of exporters is due to the exploitation of latent scale economies rather than learning-by-exporting. To discriminate between learning effects and scale effects is beyond the scope of the paper ${ }^{19}$. Note however that the conjecture that scale effects may be important could be consistent with our view that exporting firms encounter a decrease in their relative performance during the run-up to export activity, and then, in a second step, benefit from the specific investments they made. In this case, they would reach the benefices of exporting through the enlargement of their scale of production while serving distant markets.

\section{The U-Shaped Productivity Pattern of New Exporters}

The findings in the previous section lead us to focus on the TFP dynamics of a typical French manufacturing firm when it decides to expand its activities to foreign markets. In order to fully account for the presence of a U-Shaped productivity pattern, we need then to unravel the productivity dynamics of new exporters. We do so by tracing back the TFP histories of new exporters setting the benchmark value for each firm at a unique point in time. Specifically, we follow Jacobson et al. (1993) and test the following econometric specification ${ }^{20}$ :

$$
\ln T F P_{i t}=\alpha+\sum_{\substack{\tau=-5 \\ \tau \neq 0}}^{\tau=5} \lambda_{\tau} \times \mathrm{T}_{\tau}+\sum_{t} \delta_{t} \times D_{t}+\mu_{i}+\varepsilon_{i t}
$$

where $\alpha$ is a constant, $\delta_{t}$ catches the year $D_{t}$ specific effect common to all firms, $\mu_{i}$ catches persistent but unobserved heterogeneity of firms, and $\varepsilon_{i t}$ is the error term with the usual distributional properties. Here, our parameters of interest are $\lambda_{\tau}$, where $\tau \in\{-5 ;+5\}$ and $\mathrm{T}_{\tau}$ is a dumy variable indicating the period prior or after first entry into export markets. Would the 
U-shaped productivity pattern hold true, the series of parameter estimates for $\lambda_{\tau}$ should first decrease prior to entry into export markets to then increase contemporaneous, and perhaps after, entry into export markets. To facilitate interpretations, we choose the reference period to be at $\tau=0$, the actual year of entry into foreign markets for new exporters.

[Table 8 about here.]

Table 8 comfirms the existence of the U-Shaped pattern. It shows that the TFP histories of new exporters can be decomposed in three phases. During a pre-entry phase, TPF significantly decreases while capital, and to a lesser extent, intermediate inputs increase. LP of new exporters keeps growing during all the pre-entry phase as output increases and labor input remains almost unchanged. Contemporaneous to the year of entry, new exporters experience dramatic changes in all variables: output grows by $21 \%$ the year of entry while labour grows by almost $6 \%$, capital by $19 \%$ and intermediate inputs by $28 \%$. These positive changes allow new exporters to recover high TFP levels, as TFP increases by no less than $4.5 \%$ the year of entry. LP also goes through a spectacular rise of about $15 \%$ contemporaneous to the year of entry. During the post-entry phase, LP keeps increasing at a steady rate of about 2 to $3 \%$ per year whereas TFP gains remain more uncertain, albeit significant for some period.

All in all, these results are consistent with the idea that new exporters endure specific sunk costs during a run-up phase preceding their entry into export markets. During this preparatory phase, TFP decreases sharply. After that, the exporting firm's TFP increases as it benefits from its earlier investments. This recovery is almost all contemporaneous with the first year of exports.

A crucial feature of the U-Shaped TFP pattern is that it may induce new exporters to temporarily loose their productivity advantage over non exporting firms. We further illustrate this feature in figure 1 below, which plots the TFP dynamics of New Exporters and Never Exporters across the eleven-year window, the median year 0 being the year of first exports ${ }^{21}$. What stands out in figure 1 is the sharp decrease in Relative TFP in the run-up phase.

[Figure 1 about here.]

To check the robustness of this feature more thoroughly, Table 9 presents the mean TFP values for NewEs relative to NEs for each period, controlling for industry-year, cohort and sizeclass specific effects and expressing all values relative to $\mathrm{NEs}^{22}$. The first column presents the results for the same sample of firms as that employed in the graph. Overall, the inverted ranking between NewEs and NEs some times before the entry into export markets is a persistent pattern. 
Future exporters are significantly more productive five years before first exports and significantly less productive in the run-up phase to exports. We observe a sharp increase in relative TFP contemporaneous with the year of entry into foreign markets, of about 3 percentage points. In columns 2 and 3, we test the robustness of the U-shaped patterns in different ways. The second column excludes firms with TFP values in the bottom and top $1 \%$ of the TFP distribution at least once in the eleven-year window, screening out 471 firms (around 5\% of firms). The TFP U-shaped pattern persists, with the difference that the initial productivity advantage loses its significance. The run-up phase to exports is still associated with TFP losses, relative to NEs, whereas exporting remains associated with significant improvement in productive efficiency for a period of three years. In column 3 , we include firms already present at period $t-5$. Note that this reduces the number of NewEs and NEs by $65 \%$ and $27 \%$ respectively, implying that firms begin exporting at an early age. The U-shaped pattern is corroborated; future exporters are significantly more productive five years before first exports, then become significantly less productive the year immediately before starting their export activity. Ex post efficiency gains are less clearcut; no systematic differences can be observed between exporting and non exporting firms. However, this implies that there are TFP gains contemporaneous with the year of first exports $^{23}$.

[Table 9 about here.]

The remaining columns in Table 9, focus on specific sub-samples in the database in order to reveal the type of mechanisms underlying the U-shaped pattern. The fourth column includes only firms with an export intensity strictly above $5 \%$ at the year of first exports, which excludes nearly 2,000 exporting firms. We find a more pronounced U-shaped dynamic, where exporters first enjoy a TFP advantage of almost $3 \%$ at time $t-5$ to then coping with a significant and negative TFP gap between 2 and 4\%. There are remarkable efficiency improvements after entry, with a prominent 6 percentage-point rise contemporaneous with entry. These results indicate that both pre-entry sunk costs and post-entry profits are proportional to export intensity. Concerning pre-entry sunk costs, we could hypothesise that at the time of the decision to export, sunk costs are variable in the sense that they are proportional to expected future profits. Notably, a greater export intensity is likely to be positively correlated with the number of destination markets, increasing sunk costs with each new foreign market added. Concerning ex-post TFP gains, the positive association between export intensity and TFP gains is consistent with the idea that learning effects are larger for firms which commit significantly into export markets. 
In columns 5 and 6 , we group industries by quartile of capital intensity $(K / L)$, distinguishing between low (quartile 1) and high (quartile 4) capital intensive industries ${ }^{24}$. The objective is to determine the nature of the sunk costs in terms of capital deepening and/or variable costs. In more capital intensive industries, future exporters should face larger investments, which in turn should translate in a more pronounced U-shaped pattern than in less capital intensive industries. The results tend to confirm this intuition. Although not significantly different, the sunk costs of future exporters are higher for firms in capital intensive industries $\left(Q_{K / L}^{4}\right)$ than for those in more labour intensive industries $\left(Q_{K / L}^{1}\right)$, where the dynamic is flatter. Lastly columns 7 and 8 group industries according to the OECD definition of high-technology and low-technology sectors $^{25}$. This allows us to investigate whether the U-shaped pattern is sensitive to sectoral technological intensity. Our main conjecture here is that sunk costs of entry into exports markets could be relatively higher in high tech-sectors as they are likely to be linked to investment in technology acquisition. We find that sunk costs are indeed higher in high tech industries, suggesting that technology acquisition is an important element of firms export strategies in those sectors. Surprisingly, ex post TFP gains look more uncertain in high tech industries. This conflicts with what we have observed thus far, namely that larger sunk costs usually equate with substantial increases in TFP levels after entry into export markets. We attribute this weakness to two main factors. First, technology acquisition acts like a transient negative shock on firm productive efficiency in that it disrupt existing coordination mechanisms. In this case, learning lags may endure for longer in high-technology industries. Second, investments in new technologies are usually associated with more rapid physical depreciation, exceeding the value of $\delta_{t}$ used in the perpetual inventory method (PIM) (Appendix A). Hence the PIM runs the risk of overestimating $K$ and underestimating TFP, as firms invest in new technologies (?).

Overall, the U-shaped TFP dynamic is robust to all sub-sample decompositions, implying that future exporters, while initially more productive, have to cope with significant productivity losses prior to entry into export markets. TFP gains are mainly contemporaneous with entry, consistent with the view that firms first invest in enlarging their productive capacity and then reap the benefits of their sunk investments. This sequence is more pronounced when firms: commit significantly to export markets and belong to capital intensive and high technology sectors. 


\section{Conclusion}

The relationship between Trade and Productivity, traditionally investigated within macro-economic frameworks, has received renewed attention in micro-econometric studies. This paper contributes to this surge of interest and extends the set of available micro-level evidence to France. In our study, we found that the typical productivity path of a French manufacturing firm that decides to enter into export activity is U-shaped. It is a path along which firms first have to cope with sunk costs in order to export, and reap the benefits of expanded sales to foreign markets. French data are consistent with recent theoretical advances in international trade theory that emphasise market selection as the main reason for the superior productivity of exporters relative to non-exporters. Nevertheless, our findings show that a good deal of the costs involved in entry to foreign markets occur before entry, temporarily decreasing the TFP of future exporters. This basic finding may open a new case in favor of export promotion policies as the latter may help efficient firms to face the transient difficulties due to the time lag between sunk investments and non-immediate returns. Behind those policy implications, our results suggest at least three avenues for future research.

First, it could be interesting to test whether the U-shaped productivity path holds for other countries. In the case of France, we showed that the productivity decrease of future exporters is large enough to invert the usual ranking in the performances of both exporting and non-exporting firms some times prior to entry into export markets. An explanation for this result, could be the relatively high rate of participation of French firms in international trade compared to its main industrialized trade partners. If one accepts the proposition that a higher participation rate equates with less efficient firms entering export markets, the end result would be to lower all annual mean points down to values where on average Never Exporters outperform New Exporters prior to entry. This view does not preclude other countries from having similar productivity dynamics, while it is compatible with the presence of a TFP bonus three years before entry.

A second avenue for future research concerns the evaluation of ex post productivity gains using matching methods. Such methods have been introduced recently in order to evaluate more accurately the benefits from entry into foreign markets (Girma et al., 2004). They require each exporting firm to be matched with its closest non-exporting counterpart - usually in the year prior to first exports. The comparison of productivity levels after entry into export markets is then based on two groups of firms with supposedly similar ex ante performance. However, if future exporters experience a drop in relative performance because they are planning to export, 
such matching techniques could paradoxically biased the estimation of TFP gains du to the entry into export markets.

The third suggestion for research is linked to the absence of clear evidence in favour of learning-by-exporting. Although consistent with most prior contributions, our results should be interpreted with care. The reason is that there could be a systematic underestimation of postentry TFP gains for new exporters for two reasons. First, as previously mentioned, investments in new technologies increase the rate of physical depreciation above the rate used in PIM. Hence we overestimate $K$ - underestimate $T F P$ - as firms catch-up with the productivity frontier. Second, new exporters are likely to have less market power when they enter a distant market. Applying the domestic output price deflator may incorrectly lead to a systematic underestimation of $Y$ underestimation of TFP - which becomes more pronounced as firms export a large share of their sales to foreign markets. Future research should address error measurement in productivity in greater detail in order to either support or invalidate the learning-by-exporting hypothesis. 


\section{References}

Acemoglu, D., Aghion, P. and Zilibotti, F. (2002), 'Distance to frontier, selection, and economic growth'.

Altomonte, C. and Barratieri, A. (2006), 'Competitive gains from trade and the product mix: Evidence from italian firms', paper presented at the ETSG 2006 conference in Vienna, 7-9 September .

Alvarez, R. and Lopez, R. A. (2005), 'Exporting and performance: Evidence from chilean plants', Canadian Journal of Economics 38(4), 1384-1400.

Andersson, M. and Johansson, B. (2006), 'Product innovation, export and location of entrepreneurship', Royal Institute of Technology, CESIS-Working Paper Series in Economics and Institutions of Innovation (75).

Aw, B. Y., Chung, S. and Roberts, M. J. (2000), 'Productivity and turnover in the export market: Micro-level evidence from the republic of korea and taiwan (china)', World Bank Economic Review 14(1), 65-90.

Baldwin, J. R. and Gu, W. (2003), 'Export-market participation and productivity performance in canadian manufacturing', Canadian Journal of Economics 36(3), 634-57.

Bernard, A. B., Eaton, J., Jensen, J. B. and Kortum, S. (2003), 'Plants and productivity in international trade', American Economic Review 93(4), 1268-90.

Bernard, A. B. and Jensen, J. B. (1995), 'Exporters, jobs, and wages in u.s. manufacturing: 1976-1987', Brookings Papers on Economic Activity 0(0), 67-112.

Bernard, A. B. and Jensen, J. B. (1999), 'Exceptional exporter performance: Cause, effect, or both?', Journal of International Economics 47(1), 1-25.

Bernard, A. B. and Wagner, J. (1997), 'Exports and success in german manufacturing', Weltwirtschaftliches Archiv 133(1), 134-57.

Castellani, D. (2002), 'Export behavior and productivity growth: Evidence from italian manufacturing firms', Weltwirtschaftliches Archiv/Review of World Economics 138(4), 605-28.

Caves, D. W., Christensen, L. R. and Diewert, W. E. (1982), 'Multilateral comparisons of output, input, and productivity using superlative index numbers', Economic Journal 92(365), 73-86. 
Clerides, S. K., Lach, S. and Tybout, J. R. (1998), 'Is learning by exporting important? microdynamic evidence from colombia, mexico, and morocco', Quarterly Journal of Economics 113(3), 903-47.

Delgado, M. A., Farinas, J. C. and Ruano, S. (2002), 'Firm productivity and export markets: A non-parametric approach', Journal of International Economics 57(2), 397-422.

Eaton, J., Kortum, S. and Kramarz, F. (2004), 'Dissecting trade: Firms, industries, and export destinations', American Economic Review 94(2), 150-54.

Emami Namini, J. and Lopez, R. A. (2002), 'Random versus conscious selection into export markets: Theory and empirical evidence', mimeo .

Evenson, R. E. and Westphal, L. E. (1995), 'Technological change and technology strategy', Elsevier Science, North Holland pp. 2209-99.

Girma, S., Greenaway, D. and Kneller, R. (2004), 'Does exporting increase productivity? a microeconometric analysis of matched firms', Review of International Economics 12(5), 85566.

Good, D. H., Nadiri, M. I. and Sickles, R. (1997), Handbook of applied econometrics: Microeconometrics, Blackwell, Oxford, chapter Index Number and Factor Demand Approaches to the Estimation of Productivity.

Greenaway, D., Gullstrand, J. and Kneller, R. (2005), 'Exporting may not always boost firm productivity', Review of World Economics/Weltwirtschaftliches Archiv 141(4), 561-82.

Greenaway, D. and Kneller, R. (2005), 'Firm heterogeneity, exporting and foreign direct investment: A survey', University of Nottingham Research Paper Series No. 2005/32.

Hallward-Driemeier, M., Iarossi, G. and Sokoloff, K. L. (2002), 'Exports and manufacturing productivity in east asia: A comparative analysis with firm-level data', NBER Working Paper No. W8894. .

Helpman, E., Melitz, M. J. and Yeaple, S. R. (2004), 'Export versus fdi with heterogeneous firms', American Economic Review 94(1), 300-316.

Isgut, A. E. (2001), 'What's different about exporters? evidence from colombian manufacturing', Journal of Development Studies 37(5), 57-82. 
Jacobson, L., LaLonde, R. and Sullivan, D. (1993), 'Earning losses of displaced workers', American Economic Review 83(4), 685-709.

Jean, S. (2002), 'International trade and firms' heterogeneity under monopolistic competition', Open Economies Review 13(3), 291-311.

Kimura, F. and Kiyota, K. (2006), 'Export, fdi, and productivity: Dynamic evidence from japanese firms', Forthcoming in Review fo World Economics .

Koenig, P. (2005), 'Agglomeration and the export decision of french firms', CREST Discussion Paper 2005-02.

Kraay, A. (1999), 'Exports and economic performance: Evidence from a panel of chinese enterprises (english version of)', Revue d'Economie ud Développement 99(1-2), 183-207.

Lopez, R. A. (2005), 'Trade and growth: Reconciling the macroeconomic and microeconomic evidence', Journal of Economic Surveys 19(4), 623-48.

Medin, H. (2003), 'Firms' export decisions-fixed trade costs and the size of the export market', Journal of International Economics 61(1), 225-41.

Melitz, M. J. (2003), 'The impact of trade on intra-industry reallocations and aggregate industry productivity', Econometrica 71(6), 1695-1725.

Melitz, M. J. and Ottaviano, G. I. P. (2005), 'Market size, trade, and productivity', National Bureau of Economic Research, Inc, NBER Working Papers: 11393.

Nelson, R. R. and Pack, H. (1999), 'Firm competencies, technological catch-up, and the asian miracle', University of Michigan Press pp. 197-219.

Pack, H. and Page, John M., J. (1994), 'Accumulation, exports, and growth in the high-performing asian economies', Carnegie-Rochester Conference Series on Public Policy 40(0), 199-236.

Tybout, J. R. (2001), 'Plant- and firm-level evidence on "new" trade theories', National Bureau of Economic Research, Inc, NBER Working Papers: 8418.

Van Biesebroeck, J. (2005), 'Exporting raises productivity in sub-saharan african manufacturing firms', Journal of International Economics 67(2), 373-91. 
Wagner, J. (2005), 'Exports and productivity: A survey of the evidence from firm level data', Working Paper Series in Economics, 4, University of Lneburg, Institute of Economics. .

Westphal, L. E. (1990), 'Industrial policy in an export-propelled economy: Lessons from south korea's experience', Journal of Economic Perspectives 4(3), 41-59.

Yeaple, S. R. (2005), 'A simple model of firm heterogeneity, international trade, and wages', Journal of International Economics 65(1), 1-20. 


\section{Notes}

${ }^{1}$ Those papers use a valuable data source that complements the one used in the present paper, provided by the French Customs Statistic Services, which includes firm-level information on the destinations of exports

${ }^{2}$ These studies differ, however, in a variety of ways: nature of the dataset - sample versus census; unit of analysis - plant versus firm; nature of the temporal series - continuous years versus non-continuous years; time span of the series; productivity measurement - labour productivity versus TFP; parametric approach versus non parametric approach; etc.

${ }^{3}$ There are two main sources of cross-country differences. First, the trade and competition policies of countries may differ (Tybout, 2001) and this is likely to alter the strength of market selection forces; second, countries may differ in terms of their relative distance from the technological frontier (Acemoglu et al., 2002), and this is likely to affect the possibilities for learning.

${ }^{4}$ US plant data Bernard and Jensen (1999) show a TFP advantage in favour of new exporters of $6-8 \%$ points on average 3 years before initial exports; Colombian plant data, Isgut (2001) report a Labour Productivity advantage of $20-24 \%$ in favour of new exporters, again 3 years prior to entry; Canadian plant-level data, Baldwin and Gu (2003) report a LP advantage of 15\% and a TFP advantage of $7 \%$ for future exporters.

${ }^{5}$ Delgado et al. Delgado et al. (2002) found significant learning effects for only a sub-sample of young firms.

${ }^{6}$ The export intensity of the industry is calculated by summing sales and exports for all manufacturing firms and then computing the ratio at the industry level. The export intensity at firm level is the result of computing the ratio of export over sales for every firm and then computing the arithmetic average for exporting firms only.

${ }^{7}$ We computed the participation rate for manufacturing sectors at the 4 digit level, which yielded more than 286 subsectors. No subsector was exclusively focused on the domestic market, and very few (less than 5) were solely engaged in exporting. We found that for most subsectors (266) the participation rate was higher than $50 \%$. 
${ }^{8}$ Note that the broad picture conceals important sectoral differences. The size gap between exporters and non-exporters is particularly pronounced in sectors such as Automobiles, Transportation Machinery, Electrical and electronic components, and Electrical and electronic equipment. By contrast, in Pharmaceuticals where almost all firms (92\%) participate in international trade, the average value of firm export intensity approaches sector export intensity.

${ }^{9}$ We thank Jose Carlos Farinas for having provided us with unpublished participation rates of Spanish firms by firm classes.

${ }^{10}$ Relative values for the export premium are computed as the ratio of the mean value of exporting firms $\left(\overline{X_{E}^{\prime}}\right)$ over non-exporting firms $\left(\overline{X_{N E}^{\prime}}\right)$, multiplied by a 100 .

${ }^{11}$ The reported average values have been computed as follows. First, we computed the arithmetic mean value of all non exporters $(N E)$. Next, we computed relative TFP of firm $i$ as the difference between the $\log$ value of firm $i$ 's TFP and the mean value of NEs: $\ln T F P_{i j t c}^{r}=$ $\ln T F P_{i j t c}-\overline{\ln T F P_{j t c}^{N E}}$, where subscripts $j, t$, and $c$ denote industry, time and cohort, respectively. Finally, we computed the mean values $\overline{\ln T F P_{j t c}^{r}}$, to which Table 5 adds one and multiplies by a hundred for clarity.

${ }^{12}$ Note, however, that the TFP premium with respect to other exports (Switchers and NewEs) diminishes as the export-to-sales ratio increases for all these firms . A simple (unreported) ttest reveals that the distinction between AEs and NewEs is no longer relevant above an export intensity of $29 \%$.

${ }^{13}$ Unfortunately, information on firm age is not available in the EAE survey. Consequently, firm entry in our database may not be its "true" entry into the market. As the EAE database includes only firms with more than 20 employees, it may be that a firm had been in existence for some times before its appearance in the database.

${ }^{14}$ Emami Namini and Lopez (2002) extended the Melitz model to allow for firms consciously deciding between a high-tech, more human capital intensive technology to become exporters, and a low-tech, less human capital intensive technology to become non-exporters. They also show that Chilean firms that began as exporters not only have higher levels of productivity than other classes of firms, but they also show systematic differences in the training of their work forces, and vintages of their capital equipment. 
${ }^{15}$ It could be arguedthat the natural point of departure is to explain the causality underlying the firm's decision to export. This method was followed by Bernard and Jensen (1999), Castellani (2002) and Alvarez and Lopez (2005) by means of a binary response model, explaining the firm's decision to export as a function of firm characteristics. In our case however, we are interested in whether future exporters are more productive than Never Exporters some years before entry into export markets. Eq.(1) has the advantage of providing a readily available proxy for the productivity gap between New Exporters and Never Exporters in percentage points, controlling for other unobserved specific effects. As emphasised by Bernard and Jensen (1999), this estimate does not depict a causal relationship.

${ }^{16}$ by "cohort" we mean the group of firms which enter into the EAE dataset the same year. We can control for the date of entry of the firm back to 1984.

${ }^{17}$ Note that the variable Export Intensity, or export-to-sales ratio, is bounded between 0 and 1.

${ }^{18}$ Unreported results show that the yearly average TFP growth rate of NewEs turn to be significant higher than NEs between $t+2$ and $t+4$.

${ }^{19}$ Specifically, it would require to go beyond the constant-returns-to-scale assumption underlying our TFP computations.

${ }^{20}$ Jacobson et al. (1993) use a close form of this specification to estimate the magnitude and the temporal pattern of displaced workers' earning losses.

${ }^{21}$ This graph is based on the mean value of TFP for both New Exporters and Never Exporters. For Never Exporters, year 0 is the average age of New Exporters when they first export, which is 5 years. For Never Exporters that are present in the database for less than five years, year 0 is the firm-specific median year. The graph allows for entry and exit of both types of firms.

${ }^{22}$ Reported values are computed in three steps. First, we subtract from all $\ln T F P_{i t}$ the industry-year specific effect $s_{j} \times d_{t}$, a cohort fixed effect $v_{c}$ and a size-class effect $z_{s c}$ in order to obtain $\ln T F P_{i t}^{\prime}=\ln T F P_{i t}-\left(s_{j} \times d_{t}\right)-v_{c}-z_{s c}$, where all fixed effects are defined as differences of group means from overall sample means. Second, we computed the TFP of NewEs relative to NEs as the difference between the transformed TFP value of firm $i$ 's TFP $\left(T F P_{i t}^{\prime}\right)$ and the mean value of never exporters: $\ln T F P_{i t, E}^{r^{\prime}}=\ln T F P_{i t, E}^{\prime}-\overline{\ln T F P_{N E}^{\prime}}$. Finally, we computed the 
mean values $\overline{\ln T F P_{E}^{r^{\prime}}}$, to which Table 9 adds 1 and multiplies by 100 for clarity.

${ }^{23}$ These results should be taken with caution due to the declining number of observations after period $t=0$.

${ }^{24}$ To do this, we sum firm level capitals stocks $K$ and labour $L$ by industries at the three digit level (naf114), which corresponds to 53 industries. We then compute the capital intensity ratio $(K / L)$ by industry and define industry groups according to their quartiles.

${ }^{25} \mathrm{We}$ characterise the sectors according to R\&D intensity as proposed by the OECD. Essentially this aggregates manufacturing industries into four categories based on average R\&D intensity across a range of OECD countries: High-, Medium-High, Medium-Low, and Low technology. 


\section{A Main Variables Used in the Dataset}

All nominal output and inputs variables are available at firm level. Industry level data are used for price indexes, worked hours and depreciation rates.

Output. Our Output variable is Gross output deflated using sectoral price indexes published by INSEE (French System of National Accounts).

Labour. We compute our Labour variable by multiplying the number of effective workers (i.e. number of employees plus number of outsourced workers minus workers taken from other firms) by average worked hours. The annual series for worked hours are available at the 2-digit industry level and provided by GGDC Groningen Growth Development Center). This choice was made because there are no data in the EAE survey on hours worked. Note also that between 1999 and 2000 there was a substantial drop in number of worked hours occurs due to the specific "French 35 hour working week policy" (On average, worked hours fell from 38.39 in 1999 to 36.87 in 2000).

Capital input Capital stocks are computed from investment and book value of tangible assets (we rely on book value reported at the end of the accounting exercise), following the traditional PIM

$$
K_{t}=\left(1-\delta_{t-1}\right) K_{t-1}+I_{t}
$$

where $\delta_{t}$ is the depreciation rate and $I_{t}$ is real investment (deflated nominal investment). Both investment price indexes and depreciation rates are available at the 2-digit industrial classification from the INSEE data series.

Intermediate inputs. Intermediate inputs are defined as purchases of materials and merchandise, transport and travel, and miscellaneous expenses. They are deflated using sectoral price indexes for intermediate inputs published by INSEE (French System of National Accounts).

Input cost shares. With $\mathrm{w}, \mathrm{c}$ and $\mathrm{m}$ respectively representing wage rate, user cost of capital and price index for intermediate inputs $C T_{k t}=w_{k t} L_{k t}+c_{I t} K_{k t}+m_{I t} M_{k t}$ represents the total cost of production of firm $\mathrm{k}$ at time $\mathrm{t}$. Labour, capital and intermediate inputs cost shares are then respectively given by

$$
s_{L k t}=\frac{w_{k t} L_{k t}}{C T_{k t}} ; s_{K k t}=\frac{c_{I t} K_{k t}}{C T_{k t}} ; s_{M k t}=\frac{m_{I t} M_{k t}}{C T_{k t}}
$$

To compute labour cost share, we rely on the variable "labour compensation" in the EAE 
survey. This value includes total wages paid to salaries, plus income tax withholding, and is used to approximate the theoretical variable $w_{k t} L_{k t}$. To compute the intermediate inputs cost share, we use variables for intermediate goods consumption in the EAE survey and the price index for intermediate inputs in industry $I$ provided by INSEE.

We compute the user cost of capital using Hall's (1988) methodology where the user cost of capital (i.e. the rental of capital) in the presence of a proportional tax on business income and of a fiscal depreciation formula, is given by ${ }^{26}$

$$
c_{I t}=\left(r_{t}+\delta_{I t}-\pi_{t}^{e}\right)\left(\frac{1-\tau_{t} z_{I}}{1-\tau_{t}}\right) p_{I K t}
$$

where $\tau_{t}$ is the business income tax in period $t$ and $Z_{I}$ denotes the present value of the depreciation deduction on one nominal unit investment in industry I.Complex depreciation formula can be employed for tax purposes in France. To simplify, we chose to rely on the following depreciation formula $z_{I}=\sum_{t=1}^{n} \frac{\left(1-\bar{\delta}_{I}\right)^{t-1} \delta}{(1+\bar{r})^{t-1}}$ where $\bar{\delta}_{I}$ is a mean of the industrial deprecation rates for the period 1984-2002 and $\bar{r}$ is a mean of the nominal interest rate for the period 1990-2002. 


\section{B Computation of Total Factor Productivity}

The methodology given in Caves et al. (1982) and Good et al. (1997) consists of computing the TFP index for firm $i$ at time $t$ as follows:

$$
\begin{aligned}
\ln T F P_{i t} & =\ln Y_{i t}-\overline{\ln Y_{t}}+\sum_{\tau=2}^{t}\left(\overline{\ln Y_{\tau}}-\overline{\ln Y_{\tau-1}}\right) \\
- & {\left[\begin{array}{l}
\sum_{n=1}^{N} \frac{1}{2}\left(S_{n i t}+\overline{S_{n t}}\right)\left(\ln X_{n i t}-\overline{\ln X_{n t}}\right) \\
+\sum_{\tau=2}^{t} \sum_{n=1}^{N} \frac{1}{2}\left(\overline{S_{n \tau}}+\overline{S_{n \tau-1}}\right)\left(\overline{\ln X_{n \tau}}-\overline{\ln X_{n \tau-1}}\right)
\end{array}\right] }
\end{aligned}
$$

where $Y_{i t}$ denotes real gross output produced by firm $i$ at time $t$ using the set of $n$ inputs $X_{n i t}$, where input $X$ is alternatively capital stocks $(K)$, labour in terms of hours worked $(L)$ and intermediate inputs $(M) . S_{n i t}$ is the cost share of input $X_{n i t}$ in the total cost (Appendix Aprovides a full description of the variables). Subscripts $\tau$ and $n$ are indices for time and inputs, respectively. Symbols with upper bars correspond to measures for the reference point (the hypothetical firm), computed as the means of the corresponding firm level variables, over all firms in year $t$. Note that Eq.(A-4) implies that references points $\overline{\ln Y}$ and $\overline{\ln X}$ are the geometric means of the firm's output quantities and input quantities respectively, whereas the cost shares of inputs for representative firms $\bar{S}$ are computed as the arithmetic mean of the cost share of all firms in the dataset.

This methodology was popularised in the export-productivity literature thanks to the contributions by Aw et al. (2000) and Delgado et al. (2002). It is particularly well suited to comparisons within firm-level panel data sets across industries as it guarantees the transitivity of any comparison between two firm-year observations in expressing each firm's input and output as deviations from a single reference point. Moreover, the index measures the proportional difference in the TFP of any firm $i$ against the reference firm. This latter is computed once for the whole sample, implying that productivity measures at firm level also embody productivity differences across sectors. Lastly, first-differencing the logarithmic values of TFP measures can be interpreted as gaps in percentage points if they remain small. 
Table 1: Descriptive Statistics of the Sample (Year 2002)

\begin{tabular}{lccccc}
\hline & Nb. & & Firm & Sector & Relative \\
& firms & $P R^{a}$ & EI $^{b}(\%)$ & EI $^{c}(\%)$ & Size $^{d}(\%)$ \\
& & & & & \\
\hline & 20,726 & 72.8 & 23.1 & 41.2 & 287 \\
All Manufacturing & & & & & \\
Clothing & 1,212 & 69.9 & 24.8 & 33.3 & 186 \\
Printing and publishing & 1,667 & 62.6 & 8.2 & 7.1 & 143 \\
Pharmaceuticals & 513 & 92.0 & 30.4 & 33.1 & 245 \\
House equipment and furnishings & 1,303 & 82.7 & 24.2 & 30.7 & 303 \\
Automobile & 559 & 76.4 & 24.4 & 50.6 & 812 \\
Transportation machinery & 307 & 77.2 & 34.5 & 57.7 & 678 \\
Machinery and mechanical equipment & 3,764 & 70.4 & 23.6 & 36.8 & 264 \\
Electrical and Electronic equipment & 1,131 & 74.6 & 30.3 & 48.1 & 374 \\
Mineral industries & 1,189 & 51.8 & 21.9 & 21.0 & 334 \\
Textile & 1,129 & 80.6 & 29.4 & 35.7 & 176 \\
Wood and paper & 1,276 & 68.6 & 19.0 & 28.9 & 252 \\
Chemicals & 2,177 & 83.8 & 25.4 & 37.9 & 221 \\
Metallurgy. Iron and Steel & 3,602 & 71.7 & 19.4 & 32.3 & 270 \\
Electric and Electronic components & 897 & 78.1 & 27.3 & 49.1 & 448 \\
& & & & & \\
\hline
\end{tabular}

${ }^{a}$ PR: Participation Rate

${ }^{b}$ Firm EI: Arithmetic Mean of Export Intensity of firms

${ }^{c}$ Sector EI: Export Intensity of sector

${ }^{d}$ Relative size: size of exporters relative to non exporters 
Table 2: Participation rates and mean export intensity in OECD countries

\begin{tabular}{|c|c|c|c|}
\hline Country & $\begin{array}{l}\text { Part. } \\
\text { rate }\end{array}$ & $\begin{array}{l}\text { Export } \\
\text { Intensity }\end{array}$ & Sources \\
\hline France & $72 \%$ & $21 \%$ & $\begin{array}{l}\text { Our dataset } \\
\text { Firm-level data (1990-2002) average figures }\end{array}$ \\
\hline Germany & $44 \%$ & $40 \%$ & $\begin{array}{l}\text { Bernard et Wagner (1997) } \\
\text { Plant-level data (1978-1992) } 1992 \text { figures }\end{array}$ \\
\hline Great Britain & $66 \%$ & $25 \%$ & $\begin{array}{l}\text { Greeneway and Kneller (2005) } \\
\text { Firm-level data (1991-1997) } 1995 \text { figures }\end{array}$ \\
\hline Italy & $73 \%$ & $24 \%$ & $\begin{array}{l}\text { Castellani (2002) } \\
\text { Firm-level data (1994-1997) average figures }\end{array}$ \\
\hline Spain & $41 \%$ & $25 \%$ & $\begin{array}{l}\text { Delgado, Farinas et Ruano (2002) } \\
\text { Firm-level data (1991-1996) average figures }\end{array}$ \\
\hline Sweden & $89 \%$ & $36 \%$ & $\begin{array}{l}\text { Hansson and Nan Ludin (2004) } \\
\text { Firm-level data (1999 data) }\end{array}$ \\
\hline United States & $21 \%$ & $12 \%$ & $\begin{array}{l}\text { Bernard and Jensen (2004) } \\
\text { Plant-level data (1987-1992) } 1992 \text { figures }\end{array}$ \\
\hline
\end{tabular}


Table 3: Firm Export Behaviour, by Size Classes

\begin{tabular}{|c|c|c|c|c|c|c|c|c|}
\hline \multirow[b]{2}{*}{ Size class } & \multirow[b]{2}{*}{ Obs. $(\%)$} & \multirow[b]{2}{*}{$\mathrm{EI}^{a}$} & \multicolumn{6}{|c|}{$\mathrm{PR}^{a}$, According to $\mathrm{EI}^{a}$ Threshold } \\
\hline & & & $>0 \%$ & $\geq 5 \%$ & $\geq 10 \%$ & $\geq 15 \%$ & $\geq 35 \%$ & $\geq 50 \%$ \\
\hline All & 100.0 & 20.5 & 71.5 & 47.1 & 37.0 & 30.3 & 15.6 & 9.3 \\
\hline $20-49$ & 57.0 & 16.3 & 62.8 & 36.2 & 26.8 & 21.1 & 9.9 & 5.8 \\
\hline $50-249$ & 34.1 & 22.3 & 80.4 & 56.7 & 45.5 & 37.6 & 19.4 & 11.8 \\
\hline $250-499$ & 4.9 & 30.1 & 91.5 & 76.0 & 65.5 & 56.8 & 33.1 & 20.2 \\
\hline$\geq 500$ & 3.9 & 34.4 & 95.6 & 84.2 & 75.8 & 68.1 & 43.5 & 26.3 \\
\hline
\end{tabular}

${ }^{a}$ See previous table footnotes. 
Table 4: The Export Premium, by Size Classes

\begin{tabular}{lccccc}
\hline & & \multicolumn{5}{c}{ Number of employees } \\
\cline { 3 - 6 } & All firms & $20-49$ & $50-249$ & $250-499$ & $\geq 500$ \\
& & & & & \\
\hline & & & & & \\
Mean Number of Non Exp. Firms & 6,215 & 4,622 & 1,462 & 92 & 38 \\
Mean Number of Exp. Firms & 15,614 & 7,810 & 5,986 & 984 & 834 \\
& & & & & \\
Output $(Y)$ & 257.2 & 143.8 & 153.0 & 134.8 & 182.4 \\
Labour $(L)$ & 198.6 & 103.7 & 115.0 & 102.4 & 102.0 \\
Labour Productivity $(Y / L)$ & 140.4 & 138.9 & 134.2 & 131.7 & 127.3 \\
Capital Intensity $(K / L)$ & 124.5 & 115.4 & 120.6 & 115.5 & 101.1 \\
Wage per employee & 110.3 & 110.1 & 111.0 & 105.5 & 101.9 \\
& & & & & \\
\hline
\end{tabular}

$100=$ Non exporting firms.

All differences significant at $1 \%$ level, except values reported in italics.

All values are net from industry, year and cohort specific effects. 
Table 5: The TFP bonus, by Export Intensity Threshold

\begin{tabular}{|c|c|c|c|c|c|c|c|}
\hline & \multirow[b]{2}{*}{ Obs. } & \multicolumn{6}{|c|}{ Export intensity } \\
\hline & & $\geq 0 \%$ & $\geq 5 \%$ & $\geq 10 \%$ & $\geq 20 \%$ & $\geq 30 \%$ & $\geq 40 \%$ \\
\hline & & \multicolumn{6}{|c|}{ All firms } \\
\hline Always Exporters & 15,918 & 104.5 & 104.5 & 104.7 & 104.9 & 105.2 & 105.5 \\
\hline New Exporters & 3,360 & 101.9 & 103.6 & 104.2 & 105.1 & 105.7 & 105.8 \\
\hline Switchers & 9,906 & 101.4 & 102.5 & 102.8 & 103.4 & 104.2 & 104.9 \\
\hline \multirow[t]{2}{*}{ Never Exporters } & 4,581 & 100.0 & & & & & \\
\hline & \multicolumn{7}{|c|}{ Continuing firms (Balanced panel) } \\
\hline Always Exporters & 4,387 & 104.0 & 103.9 & 104.0 & 104.4 & 104.8 & 105.5 \\
\hline New Exporters & 506 & 103.5 & 104.7 & 105.4 & 106.2 & 106.0 & 107.5 \\
\hline Switchers & 3,025 & 101.5 & 102.1 & 102.0 & 102.6 & 104.0 & 104.9 \\
\hline \multirow[t]{2}{*}{ Never Exporters } & 531 & 100.9 & & & & & \\
\hline & \multicolumn{7}{|c|}{ Successful entrants ${ }^{a}$} \\
\hline Always Exporters & 3,062 & 107.8 & 108.2 & 108.5 & 108.5 & 108.7 & 108.7 \\
\hline New Exporters & 762 & 103.0 & 104.2 & 104.8 & 105.9 & 106.9 & 105.7 \\
\hline Switchers & 2,533 & 102.8 & 104.6 & 105.1 & 105.6 & 106.3 & 107.0 \\
\hline Never Exporters & 760 & 100.9 & & & & & \\
\hline
\end{tabular}

${ }^{a}$ Successful Entrants are those firms which enter the database from 1990 to 1998 and survive at least 5 years.

All values are relative to the TFP of Never Exporters (row 4, all firms), controlling for industry, cohort, age and size class fixed effects. 
Table 6: Ex Ante Performance of Exporters

\begin{tabular}{|c|c|c|c|c|c|}
\hline & \multicolumn{2}{|c|}{ Levels (Eq.1) } & \multicolumn{3}{|c|}{ Growth rates (Eq.2) } \\
\hline & $t-5$ & $t-3$ & & $\frac{t-1}{t-3}$ & $\frac{t}{t-1}$ \\
\hline TFP & $\begin{array}{l}0.035 \\
{[2.70]}\end{array}$ & $\begin{array}{r}-0.019 \\
{[2.54]}\end{array}$ & $\begin{array}{r}-0.016 \\
{[3.20]}\end{array}$ & $\begin{array}{l}0.000 \\
{[0.12]}\end{array}$ & $\begin{array}{l}0.030 \\
{[5.14]}\end{array}$ \\
\hline Labour Productivity $(Y / L)^{a}$ & $\begin{array}{l}0.128 \\
{[3.32]}\end{array}$ & $\begin{array}{l}0.075 \\
{[3.32]}\end{array}$ & $\begin{array}{c}-0.008 \\
{[0.77]}\end{array}$ & $\begin{array}{l}0.011 \\
{[1.95]}\end{array}$ & $\begin{array}{l}0.082 \\
{[6.69]}\end{array}$ \\
\hline Output $(Y)$ & $\begin{array}{l}0.130 \\
{[3.36]}\end{array}$ & $\begin{array}{l}0.074 \\
{[3.30]}\end{array}$ & $\begin{array}{l}0.009 \\
{[0.76]}\end{array}$ & $\begin{array}{l}0.023 \\
{[3.41]}\end{array}$ & $\begin{array}{l}0.140 \\
{[9.66]}\end{array}$ \\
\hline Labour $(L)^{a}$ & $\begin{array}{r}-0.024 \\
{[0.50]}\end{array}$ & $\begin{array}{l}0.008 \\
{[0.31]}\end{array}$ & $\begin{array}{l}0.017 \\
{[2.04]}\end{array}$ & $\begin{array}{l}0.012 \\
{[2.40]}\end{array}$ & $\begin{array}{l}0.057 \\
{[6.44]}\end{array}$ \\
\hline Capital Stocks $(K)$ & $\begin{array}{l}0.191 \\
{[2.07]}\end{array}$ & $\begin{array}{l}0.271 \\
{[5.18]}\end{array}$ & $\begin{array}{l}0.029 \\
{[1.68]}\end{array}$ & $\begin{array}{l}0.026 \\
{[3.22]}\end{array}$ & $\begin{array}{l}0.048 \\
{[3.78]}\end{array}$ \\
\hline Intermediate Inputs $(M)$ & $\begin{array}{l}0.212 \\
{[3.08]}\end{array}$ & $\begin{array}{l}0.247 \\
{[6.14]}\end{array}$ & $\begin{array}{l}0.041 \\
{[2.24]}\end{array}$ & $\begin{array}{l}0.032 \\
{[3.12]}\end{array}$ & $\begin{array}{l}0.188 \\
{[8.35]}\end{array}$ \\
\hline
\end{tabular}

${ }^{a}$ Size not included in the vector of explanatory variables.

$N=3,609$ for $\tau=1 ; 3, N=2,173$ for $\tau=5$.

$t$-stat in brackets.

All parameters significant at $5 \%$ level, except those in italics. 
Table 7: Ex Post Performance of Exporters

\begin{tabular}{|c|c|c|c|c|c|c|}
\hline & \multirow{2}{*}{\multicolumn{2}{|c|}{$\begin{array}{c}\text { Levels (Eq.3) } \\
t+5\end{array}$}} & \multicolumn{4}{|c|}{ Growth rates (Eq.4) } \\
\hline & & & \multicolumn{2}{|c|}{$\frac{t+3}{t}$} & \multicolumn{2}{|c|}{$\frac{t+5}{t+3}$} \\
\hline & $\beta_{1}$ & $\beta_{2}$ & $\beta_{1}$ & $\beta_{2}$ & $\beta_{1}$ & $\beta_{2}$ \\
\hline TFP & $\begin{array}{l}0.021 \\
{[1.81]}\end{array}$ & $\begin{array}{l}0.067 \\
{[2.06]}\end{array}$ & $\begin{array}{l}0.002 \\
{[0.68]}\end{array}$ & $\begin{array}{l}0.002 \\
{[0.33]}\end{array}$ & $\begin{array}{r}-0.005 \\
{[1.26]}\end{array}$ & $\begin{array}{l}0.011 \\
{[0.93]}\end{array}$ \\
\hline Labour Productivity $(Y / L)^{a}$ & $\begin{array}{l}0.315 \\
{[8.08]}\end{array}$ & $\begin{array}{l}0.184 \\
{[1.64]}\end{array}$ & $\begin{array}{c}0.013 \\
2.31\end{array}$ & $\begin{array}{c}-0.022 \\
{[1.36]}\end{array}$ & $\begin{array}{r}-0.009 \\
{[1.18]}\end{array}$ & $\begin{array}{l}0.028 \\
{[1.23]}\end{array}$ \\
\hline Output $(Y)$ & $\begin{array}{l}0.299 \\
{[7.74]}\end{array}$ & $\begin{array}{l}0.171 \\
{[1.54]}\end{array}$ & $\begin{array}{l}0.027 \\
{[3.75]}\end{array}$ & $\begin{array}{c}-0.012 \\
{[0.61]}\end{array}$ & $\begin{array}{l}0.000 \\
{[0.05]}\end{array}$ & $\begin{array}{l}0.018 \\
{[0.67]}\end{array}$ \\
\hline Labour $(L)^{a}$ & $\begin{array}{l}0.138 \\
{[2.61]}\end{array}$ & $\begin{array}{l}0.111 \\
{[0.73]}\end{array}$ & $\begin{array}{l}0.014 \\
{[2.64]}\end{array}$ & $\begin{array}{l}0.009 \\
{[0.66]}\end{array}$ & $\begin{array}{l}0.010 \\
{[1.39]}\end{array}$ & $\begin{array}{r}-0.010 \\
{[0.50]}\end{array}$ \\
\hline Capital Stocks $(K)$ & $\begin{array}{l}0.380 \\
{[5.05]}\end{array}$ & $\begin{array}{l}0.253 \\
{[1.16]}\end{array}$ & $\begin{array}{l}0.026 \\
{[3.45]}\end{array}$ & $\begin{array}{l}-0.007 \\
{[0.32]}\end{array}$ & $\begin{array}{l}0.018 \\
{[2.05]}\end{array}$ & $\begin{array}{r}-0.013 \\
{[0.53]}\end{array}$ \\
\hline Intermediate inputs $(M)$ & $\begin{array}{l}0.582 \\
{[9.34]}\end{array}$ & $\begin{array}{l}0.007 \\
{[0.04]}\end{array}$ & $\begin{array}{l}0.024 \\
{[2.62]}\end{array}$ & $\begin{array}{l}-0.020 \\
{[0.74]}\end{array}$ & $\begin{array}{l}0.002 \\
{[0.20]}\end{array}$ & $\begin{array}{l}0.024 \\
{[0.68]}\end{array}$ \\
\hline
\end{tabular}

\footnotetext{
${ }^{a}$ Size not included in the vector of explanatory variables.

$N=1,944$ for $\tau=5, N=2,735$ for $\tau=3$

$t$-stat in brackets.

All parameters significant at $5 \%$ level, except those in italics.
} 
Table 8: The U-Shaped TFP Dynamics of New Exporters

\begin{tabular}{lcccccc}
\hline Period & TFP & LP & Output & Labour & $\begin{array}{c}\text { Capital } \\
\text { stocks } \\
(C)\end{array}$ & $\begin{array}{c}\text { Intermediate } \\
\text { inputs } \\
(M)\end{array}$ \\
& & $(Y / L)$ & $(Y)$ & $(L)$ & & \\
-5 & -0.029 & -0.227 & -0.335 & -0.107 & -0.575 & -0.457 \\
-4 & -0.031 & -0.195 & -0.296 & -0.101 & -0.484 & -0.392 \\
-3 & -0.035 & -0.185 & -0.255 & -0.070 & -0.365 & -0.346 \\
-2 & -0.040 & -0.173 & -0.234 & -0.061 & -0.294 & -0.315 \\
-1 & -0.045 & -0.154 & -0.210 & -0.056 & -0.193 & -0.277 \\
& & & & & & \\
0 & 0.000 & 0.000 & 0.000 & 0.000 & 0.000 & 0.000 \\
& & & & & & \\
1 & 0.004 & 0.021 & 0.052 & 0.030 & 0.122 & 0.041 \\
2 & 0.003 & 0.045 & 0.103 & 0.058 & 0.238 & 0.101 \\
3 & 0.014 & 0.076 & 0.151 & 0.075 & 0.326 & 0.141 \\
4 & 0.008 & 0.098 & 0.185 & 0.087 & 0.403 & 0.188 \\
5 & 0.019 & 0.129 & 0.216 & 0.087 & 0.470 & 0.218 \\
& & & & & & \\
\hline \multirow{2}{*}{ Obs. } & 17,831 & 17,831 & 17,831 & 17,831 & 17,831 & 17,831 \\
$\mathrm{R}^{2}$ & 3,360 & 3,360 & 3,360 & 3,360 & 3,360 & 3,360 \\
& 0.020 & 0.110 & 0.160 & 0.090 & 0.350 & 0.150 \\
\hline
\end{tabular}

All values are net from industry-year, cohort and size class specific effects All parameters significant at 5\% level, except those in italics.

${ }^{a}$ NewEs: Number of New Exporters. 
Table 9: Robustness checks of the U-Shaped pattern

\begin{tabular}{rrrrrrrrr}
\hline Period & Pooled & ] $1 ; 99[$ & Bal. & $\mathrm{EI}^{>5 \%}$ & $Q_{K / L}^{1}$ & $Q_{K / L}^{4}$ & $\mathrm{LT}^{a}$ & $\mathrm{HT}^{b}$ \\
& & & & & & & & \\
-5 & 101.5 & 100.8 & 101.7 & 102.9 & 100.9 & 100.7 & 101.8 & 101.3 \\
-4 & 99.4 & 99.1 & 100.2 & 100.0 & 99.0 & 98.0 & 100.2 & 96.8 \\
-3 & 98.4 & 99.0 & 99.9 & 97.6 & 99.2 & 97.2 & 99.2 & 94.4 \\
-1 & 98.2 & 99.1 & 99.3 & 95.7 & 99.4 & 93.1 & 99.4 & 97.7 \\
0 & 98.9 & 99.7 & 98.6 & 97.6 & 100.3 & 97.1 & 101.1 & 98.9 \\
1 & 102.9 & 102.4 & 100.7 & 103.6 & 103.2 & 104.6 & 105.0 & 103.3 \\
2 & 103.2 & 103.0 & 100.8 & 103.5 & 103.1 & 104.4 & 104.4 & 100.9 \\
3 & 104.0 & 103.6 & 100.2 & 104.1 & 103.9 & 106.3 & 105.1 & 101.1 \\
4 & 102.6 & 102.9 & 100.4 & 103.8 & 104.7 & 104.1 & 104.2 & 100.5 \\
5 & 103.3 & 103.4 & 100.7 & 105.5 & 103.9 & 105.3 & 104.3 & 103.2 \\
& & & & & & & & \\
NewEs $^{c}$ & 3,360 & 3,138 & 480 & 1,402 & 1,458 & 333 & 1,256 & 301 \\
NEs $^{d}$ & 4,581 & 4,322 & 1,693 & 4,581 & 1,980 & 772 & 1,959 & 380 \\
& & & & & & & & \\
\hline $100=N_{10 v}$
\end{tabular}

$100=$ Never Exporters.

All values are net from industry-year, cohort and size class specific effects.

All parameters significant at $5 \%$ level, except those in italics.

${ }^{a}$ LT: Low technology sectors.

${ }^{b} \mathrm{HT}$ : High technology sectors.

${ }^{c}$ NewEs: Number of New Exporters.

${ }^{d}$ NEs: Number of Never Exporters. 


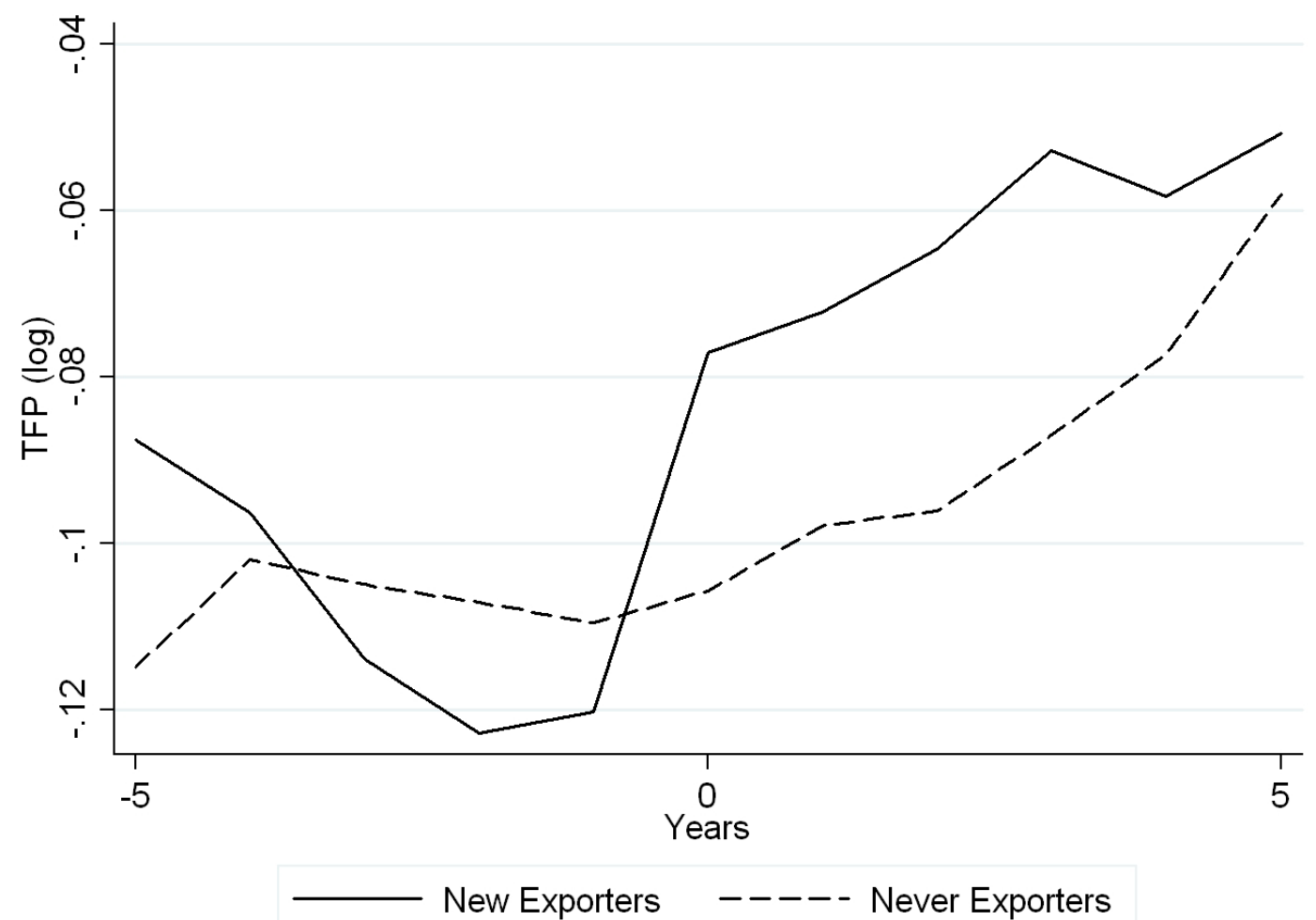

Figure 1: TFP Dynamics of New Exporters and Never Exporters 